\title{
Risiko obesitas pada anak kelas 3, 4, 5 yang tidak sarapan di SDN Kelapa Dua Wetan 03 Pagi Ciracas Jakarta Timur
}

\author{
Like Inggrid Samsudin ${ }^{a}$, Titus Priyo Harjatmo ${ }^{a, 1}$, Sugeng Wiyono ${ }^{a}$, Nils Aria Zulfianto ${ }^{a}$ \\ aJurusan Gizi Politeknik Kesehatan Kemenkes Jakarta II, Jln. Hang Jebat III/F3 Kebayoran Baru Jakarta 12120 \\ ${ }^{1}$ titoespriyo@yahoo.co.id* \\ *korespondensi penulis
}

\begin{tabular}{ll}
\hline Kata kunci: & ABSTRAK \\
Sarapan, & Latar Belakang: Jumlah anak sekolah yang melakukan sarapan pagi di Jakarta \\
Obesitas, & masih rendah padahal hal tersebut sangat penting untuk menjaga keseimbangan \\
Siswa Sekolah & asupan gizi. Sebagai gantinya, anak sekolah membeli jajanan yang kurang sehat \\
Dasar, Status & atau cenderung makan lebih banyak sehingga membuat risiko obesitas menjadi \\
Gizi & tinggi di kalangan anak sekolah. Tujuan: Penelitian ini bertujuan untuk \\
& mengetahui hubungan kebiasaan sarapan dengan status obesitas anak sekolah \\
& dasar pada siswa kelas 3,4,5 SDN Kelapa Dua Wetan 03 Pagi Ciracas Jakarta Timur. \\
& Metode: Desain penelitian ini adalah cross sectional dengan penarikan subjek \\
& secara systematic random sampling. Subjek berjumlah 123 siswa dari 196 siswa \\
& kelas 3,4,5. Data yang dikumpulkan adalah karakteristik siswa, kebiasaan sarapan, \\
& dan status gizi. Hasil: Hasil penelitian menunjukkan bahwa sebagian besar siswa \\
& tidak sarapan (51.2\%). Berdasarkan hasil uji statistik diketahui adanya hubungan \\
& antara kebiasaan sarapan dengan status gizi (p<0.05). Berdasarkan hasil analisis \\
& odd ratio dapat disimpulkan bahwa siswa yang tidak sarapan 6.2 kali (95\% CI=2.6- \\
& 14.7) berisiko terjadinya obesitas dibanding anak yang sarapan. Kesimpulan: \\
& mayoritas siswa sekolah dasar melewatkan sarapan sebelum berangkat sekolah \\
& dan hanya sebagian siswa yang sarapan secara rutin. Anak yang tidak sarapan \\
& mempunyai risiko untuk obesitas dibandingkan anak yang sarapan.
\end{tabular}

\begin{abstract}
Key words:
ABSTRACT

Breakfast,

Elementary

School Child,

Obesity,

Nutritional

Status fact, school children can get balanced nutrition from having breakfast. Instead of having breakfast, children get the energy from snacks or eat more that might make them have higher risk to be obese. Objectives: This study aims to determine the relationship of breakfast habits with nutritional status in elementary school children in grade 3,4,5 SDN Kelapa Dua Wetan 03 Pagi Ciracas, East Jakarta. Method: The cross sectional study was applied. The subjects was selected in systematic random sampling. Subjects were 123 students from 196 students in grade 3,4,5. The data collected are the characteristics of students breakfast habits and nutritional status. Results : The result showed that most students did not do breakfast $(51.2 \%)$. Based on the results of chi square test showed the relationship between breakfast habits with nutritional status $(p<0.05)$. Based on the results of odd ratio analysis can be concluded that students who skip breakfast 6.2 times (95\% CI=2.6-14.7) the risk of obesity in children who eat breakfast.Conclusion: Most elementary students skip breakfast before leaving for school and only a few students eat breakfast regularly. Students who skip breakfast have higher risk of obesity.
\end{abstract}

This is an open access article under the CC-BY-SAlicense. 


\section{Pendahuluan}

Anak usia sekolah adalah generasi penerus bagi pembangunan di masa depan dan upaya peningkatan kualitas sumber daya manusia harus dilakukan sejak dini, sistematis dan berkesinambungan ${ }^{1}$. Anak-anak sekolah dasar merupakan salah satu kelompok yang rawan mengalami gizi kurang diantara penyebabnya ialah tingkat ekonomi yang rendah dan asupan makanan yang kurang seimbang serta rendahnya pengetahuan orang tua. Anak sekolah dengan pola makan seimbang cenderung memiliki status gizi yang baik².

Berdasarkan hasil survei konsumsi pangan pada Riset Kesehatan Dasar (Riskesdas) (2010), masih banyak anak yang tidak terbiasa sarapan sehat. Sarapan merupakan sumber energi sebelum berangkat ke sekolah dan diperlukan untuk aktivitas dan belajar di sekolah³. Sarapan dibutuhkan untuk mengisi yang telah kosong selama 8-10 jam dan bermanfaat dalam meningkatkan kemampuan konsentrasi belajar dan kemampuan fisik ${ }^{4}$. Sarapan mampu memenuhi sebagian kebutuhan gizi harian yaitu 15-30\% AKG dalam rangka mewujudkan hidup sehat, aktif dan cerdas ${ }^{15}$. Konsumsi sarapan secara teratur dapat berkaitan dengan IMT normal dan berhubungan dengan berat badan yang lebih sehat ${ }^{6}$. Namun, hasil tersebut belum menunjukkan hasil yang konsisten pada penelitian lainnya ${ }^{7}$.

Berdasarkan analisis dari hasil survei dapat diketahui bahwa dari 35.000 anak usia sekolah sekitar 26,1\% sarapan hanya dengan air minum dan 44,6\% memperoleh asupan energi kurang dari 15\% kebutuhan gizi per hari4. Berdasarkan penelitian pada SD Unggulan dan Non Unggulan di Jakarta Timur diperoleh $7.83 \%$ rata-rata memiliki kebiasaan sarapan pagi pada sekolah unggulan dan $8.30 \%$ rata-rata memiliki kebiasaan sarapan pagi pada sekolah non unggulan di Jakarta Timur'.

Dari masalah tersebut, penulis ingin mengetahui hubungan sarapan dengan status gizi khususnya risiko obesitas pada anak SD khususnya di SDN Kelapa Dua Wetan 03 Pagi Ciracas Jakarta Timur.

\section{Metode}

Penelitian ini menggunakan desain studi cross sectional. Variabel dependen dalam penelitian ini adalah status obesitas anak sekolah dasar.

Penelitian ini dilakukan pada bulan Maret-April 2018 di SDN Kelapa Dua Wetan 03 Pagi Ciracas Jakarta Timur. Populasi pada penelitian ini adalah seluruh siswa kelas 3-5 yang terdapat di SDN Kelapa Dua Wetan 03 Pagi Ciracas Jakarta Timur yang berjumlah 196 orang siswa.

Teknik pengambilan sampel pada penelitian ini menggunakan teknik random sampling. Didapatkan sampel sejumlah 123 sampel yang didapat dengan perhitungan rumus sampel jumlah populasi diketahui.

Data yang dikumpulkan merupakan data primer yang bersumber langsung dari subjek. Data yang diambil meliputi variabel usia, jenis kelamin yang diukur dengan wawancara menggunakan kuesioner. Variabel berat badan, tinggi badan diukur secara antropometri. Variabel status gizi menurut indeks IMT/U dihitung berdasarkan parameter berat badan dan tinggi bada. Variabel berat badan, tinggi badan dan kebiasaan sarapan diolah secara deskriptif untuk mengidentifikasi nilai rata rata, minimum, maksimum dan standar deviasi dari variabel asupan energi-protein sarapan dan energi-protein sehari.

Data dianalisis dengan analisis deskriptif univariat dan analisis bivariat dengan menggunakan uji Chisquare dan Odd Ratio menggunakan software statistic. Penelitian ini telah lulus kaji etik dari Unit Penelitian Etik Kesehatan Politeknik Kesehatan Jakarta II. 


\section{Hasil dan Pembahasan}

Berdasarkan hasil pengumpulan data menggunakan kuesioner, gambaran umum siswa SDN Kelapa Dua Wetan 03 Pagi menurut karakteristik siswa ditampilkan pada Tabel 1.

Tabel 1. Distribusi frekuensi berdasarkan karekteristik siswa

\begin{tabular}{|c|c|c|}
\hline Karakteristik siswa & \multirow{2}{*}{$\mathrm{n}$} & \multirow{2}{*}{$\%$} \\
\hline Jenis kelamin & & \\
\hline $\begin{array}{l}\text { Perempuan } \\
\text { Laki-laki }\end{array}$ & $\begin{array}{l}57 \\
66\end{array}$ & $\begin{array}{l}46.3 \\
53.7\end{array}$ \\
\hline \multicolumn{3}{|l|}{ Umur (tahun) } \\
\hline $\begin{array}{l}8 \\
9 \\
10 \\
11 \\
12\end{array}$ & $\begin{array}{c}1 \\
22 \\
37 \\
48 \\
15\end{array}$ & $\begin{array}{c}0.8 \\
17.9 \\
30.1 \\
39.0 \\
12.2\end{array}$ \\
\hline Jumlah & 123 & 100 \\
\hline
\end{tabular}

Berdasarkan tabel diatas dapat diketahui bahwa karakteristik siswa berdasarkan jenis kelamin, sebagai besar berjenis kelamin laki-laki (46.3\%). Karakteristik siswa berdasarkan umur sebagian besar berumur 11 tahun (39.0\%).

Kebiasaan sarapan dilihat dalam beberapa kategori yaitu frekuensi sarapan, waktu sarapan, lokasi sarapan, cara memperoleh sarapan, jenis sarapan, jenis minuman sarapan, alasan tidak sarapan, dan kecukupan asupan energi dan protein.

Menurut kebiasaan sarapan disajikan pada Tabel 2.

Tabel 2. Distribusi frekuensi berdasarkan Kategori Sarapan

\begin{tabular}{lcc}
\hline \multicolumn{1}{c}{ Kategori Sarapan } & $\mathrm{n}$ & $\%$ \\
\hline Sarapan & 60 & 48.8 \\
Tidak sarapan & 63 & 51.2 \\
\hline Jumlah & 123 & 100.0 \\
\hline
\end{tabular}

Berdasarkan tabel diatas mayoritas siswa melewatkan sarapan sebelum berangkat ke sekolah (51.2\%) dan hanya (48.8\%) siswa yang sarapan secara rutin.

Melewatkan sarapan berhubungan dengan usia, jenis kelamin, etnis dan budaya, pendapatan, dan tingkat aktivitas fisik diantara anak laki-laki disekolah dasar dan anak perempuan di sekolah menengah ${ }^{6}$. Frekuensi sarapan berkontribusi untuk mengurangi peningkatan selera makan dan pencegahan terjadinya kenaikan berat badan sesuai dengan Tabel 3.

Berdasarkan Tabel 3, frekuensi sarapan (dalam minggu) siswa SDN Kelapa Dua Wetan 03 Pagi tergolong dalam kategori sering ( $\geq 4$ kali). Menurut hasil penelitian sebelumnya anak yang membiasakan mengonsumsi sarapan menambah pemenuhan kebutuhan zat gizi sehari-hari dan meningkatkan motivasi anak untuk beraktivitas². Melewatkan sarapan dan pola makan yang tidak teratur dapat menyebabkan metabolisme abnormal dan mungkin menyebabkan obesitas ${ }^{8}$.

Siswa yang sarapan pagi dibawah jam 9 atau sebelum melakukan aktivitas, lebih dapat berkonsentrasi dalam belajar, karena ketika mereka belajar disekolah perut mereka sudah terisi dengan sarapan sebelum aktivitas atau pelajaran dimulai ${ }^{9}$. 
Tabel 3. Distribusi frekuensi berdasarkan frekuensi sarapan

\begin{tabular}{lcc}
\hline Frekuensi sarapan (per minggu) & $\mathrm{n}$ & $\%$ \\
\hline Sering ( $\geq 4$ kali) & 58 & 47.2 \\
Kadang-kadang (2-3 kali) & 53 & 43.1 \\
Jarang (<2 kali) & 12 & 9.8 \\
\hline \multicolumn{1}{c}{ Jumlah } & 123 & 100 \\
\hline
\end{tabular}

Siswa melakukan sarapan sebelum jam 7.00 pagi dikarenakan kegiatan sekolah dimulai pada pukul 6.30 pagi dan sarapan dilakukan sebelum masuk sekolah atau sebelum melakukan aktivitas. Tabel 4 menunjukkan mayoritas siswa SDN Kelapa Dua Wetan 03 Pagi tergolong melakukan sarapan jam 7 pagi atau sebelum jam 9 pagi (82\%).

Jarak antara rumah ke sekolah cenderung dekat karena contoh tinggal masih di dekat lingkungan sekolah. Siswa yang melakukan sarapan disekolah biasanya membawa bekal dari rumah atau membeli makanan jajanan di sekolah.

Anak yang melakukan sarapan di rumah cenderung mengonsumsi sarapan yang lebih sehat, sedangkan anak yang mengonsumsi sarapan selain dirumah akan cenderung membeli jajanan diluar dan biasanya adalah makanan yang kurang sehat ${ }^{16}$

Kebiasaan sarapan pada anak tumbuh karena pembiasaan yang telah dilakukan sejak dini. Dalam hal ini orang tua mempunyai peran penting untuk membiasakan perilaku sarapan di pagi hari ${ }^{10}$. Selain itu orang tua juga bertanggung jawab untuk menyediakan sarapan yang mengandung gizi dan nutrisi yang dibutuhkan sehingga anak dapat tumbuh dan berkembang secara optimal. Salah satu faktor yang membentuk kebiasaan makan anak adalah lingkungan keluarga. Peran ibu dalam keluarga, terutama dalam merawat dan mengurus keluarga. Berdasarkan penelitian sebelumnya orang tua khususnya ibu mempunyai peranan penting dalam membentuk kebiasaan sarapan pada anak.

Berdasarkan Tabel 5, hampir seluruh siswa di SDN Kelapa Dua Wetan 3 Pagi melakukan sarapan di rumah (48\%).

Tabel 5. Distribusi frekuensi berdasarkan lokasi sarapan

\begin{tabular}{lll}
\hline Lokasi Sarapan & $\mathrm{n}$ & $\%$ \\
\hline Di rumah & 59 & 48.0 \\
Di sekolah & 1 & 0.8 \\
Tidak sarapan & 63 & 51.2 \\
\hline Jumlah & 123 & 100 \\
\hline
\end{tabular}

Jenis makanan yang dikonsumsi saat sarapan menentukan kualitas sarapan dan energi yang dihasilkan dari sarapan. Berdasarkan penelitian terdahulu sarana utama dari segi gizi untuk memenuhi kebutuhan energi anak sekolah adalah sarapan pagi. Tanpa sarapan pagi, akan terjadi kekosongan lambung sehingga kadar glukosa menurun. Glukosa darah merupakan sumber energi utama bagi otak, sehingga anak akan kesulitan menerima pelajaran dengan baik. ${ }^{5}$

Konsumsi sarapan sebaiknya terdiri dari makanan lengkap yaitu makanan dan minuman yang mengacu pada pedoman gizi seimbang, yaitu mengandung semua unsur gizi yang diperlukan oleh tubuh seperti pemenuhan karbohidrat dan zat gizi lainnya seperti 
protein, lemak, vitamin, mineral, air, dan serat. Secara umum, jenis komposisi pangan pada anak telah memenuhi kebutuhan minimal sarapan yakni terdiri dari makanan pokok dan lauk hewani. Berdasarkan Tabel 6 jenis sarapan yang dikonsumsi oleh siswa SD Kelapa Dua Wetan 03 Pagi.

Tabel 6. Distribusi frekuensi berdasarkan jenis sarapan

\begin{tabular}{lcc}
\hline \multicolumn{1}{c}{ Jenis sarapan } & $\mathrm{n}$ & $\%$ \\
\hline Biskuit & 3 & 2.4 \\
Bubur ayam & 1 & 0.8 \\
Nasi + LH/LN & 11 & 8.9 \\
Nasi + sayur & 2 & 1.6 \\
Nasi goreng & 33 & 26.8 \\
Roti + selai & 10 & 8.1 \\
Tidak sarapan & 63 & 51.2 \\
\hline Jumlah & 123 & 100 \\
\hline
\end{tabular}

Jika dibandingkan dengan anjuran pemberian makanan pada anak usia sekolah yang memerlukan zat gizi cukup tinggi sedianya dapat terpenuhi apabila konsumsi makanan bervariasi sehingga masih perlu ditingkatkan asupan zat gizi sarapan pada siswa ${ }^{5}$, karena bagaimanapun anak sekolah memerlukan zat gizi yang baik terutama berasal dari sarapan untuk menunjang aktivitas pada pagi hari di sekolah. Ketika seorang anak tidak mampu memenuhi gizi dirumah sebelum berangkat ke sekolah ada baiknya pemenuhan dilakukan di sekolah saat istirahat pada pagi hari. Harapannya dapat memenuhi $15 \%$ asupan gizi sarapan, sebanyak (51.2\%) anak yang tidak sarapan hal ini sejalan dengan penelitian terdahulu kebiaaan sarapan berhubungan dengan kebiasaan jajan di sekolah dengan risiko sebesar 1,5 kali, artinya anak yang tidak sarapan memiliki kecenderungan memiliki kebiasaan jajan 1,5 kali lebih besar dibandingkan anak yang sarapan².

Ketersediaan makanan sarapan di rumah sangatlah penting karena merupakan faktor yang sangat mendukung anak untuk terbiasa sarapan pagi. Jika makanan tersedia setiap hari, khususnya makanan dan minuman sarapan tentu mempengaruhi faktor psikologis si anak yang akan memberikan pengaruh dalam membentuk pola makan yang sehat pada anak ${ }^{21}$.

Berbagai faktor penyebab anak di berbagai kota besar tidak melakukan sarapan. Beberapa faktor yang memengaruhi kebiasaan sarapan antara lain: usia anak, jenis kelamin anak, pengetahuan anak mengenai kesehatan dan gizi, ketersediaan makanan pagi di rumah, waktu tempuh atau jarak antara rumah dengan sekolah, jumlah uang saku, kebiasaan jajan yang mengenyangkan ${ }^{17,18}$. Berdasarkan Tabel 7 alasan siswa tidak sarapan yaitu tertinggi dengan alasan tidak lapar (25.2\%) kemudian diikuti dengan takut terlambat (14.6\%).

Sarapan yang terlewat disebabkan oleh beberapa faktor antara lain waktu sarapan karena telat bangun pagi, merasa tidak sehat saat sarapan, tidak lapar dipagi hari, persepsi tubuh ideal bagi anak perempuan (seperti model) dikenali sebagai penjelasan karena melewatkan sarapan sebelum berangkat ke sekolah ${ }^{19}$. 
Tabel 7. Distribusi frekuensi berdasarkan alasan tidak sarapan

\begin{tabular}{lcc}
\hline Alasan tidak sarapan & $\mathrm{n}$ & $\%$ \\
\hline Kesiangan & 1 & 0.8 \\
Takut terlambat & 18 & 14.6 \\
Tidak ada waktu & 8 & 6.5 \\
Tidak lapar & 31 & 25.2 \\
Tidak nafsu makan & 2 & 1.6 \\
Tidak suka sarapan & 3 & 2.4 \\
Sarapan & 60 & 48.8 \\
\hline Jumlah & 123 & 100.0 \\
\hline
\end{tabular}

Berdasarkan Tabel 8, siswa SDN Kelapa Dua Wetan 03 Pagi Jakarta Timur rata-rata mengonsumsi energi pada saat sarapan sebesar 311.2 kalori dan rata-rata siswa konsumsi protein sebesar $10.8 \mathrm{~g}$. Energi tertinggi yang dikonsumsi siswa pada saat sarapan yaitu 730,5 kalori dan protein tertinggi dikonsumsi pada saat sarapan yaitu 29,6 g. Bila dibandingkan dengan Angka Kecukupan Gizi untuk energi dan protein pada anak sekolah pada laki-laki dan perempuan sebesar $2050 \mathrm{kkal}$ dan 50 gram. Dengan demikian asupan energi dan protein untuk sarapan memenuhi sebesar $15,2 \%$ dan $21,6 \%$. Sarapan adalah kegiatan makan dan minum yang dilakukan mulai dari bangun tidur dipagi hari sampai jam 9 untuk memenuhi sekitar 15-25\% kebutuhan gizi sehari untuk mewujudkan hidup yang sehat, aktif dan cerdas.

Tabel 8 Distribusi frekuensi berdasarkan asupan energi dan protein sarapan

\begin{tabular}{lccccc}
\hline Zat gizi & $\mathrm{n}$ & $\overline{\mathrm{X}}$ & Min & Max & SD \\
\hline Energi (Kalori) & 123 & 311.2 & 0.0 & 730.5 & 166.7 \\
Protein $(\mathrm{g})$ & 123 & 10.8 & 0.0 & 29.6 & 6.70 \\
\hline
\end{tabular}

Data asupan zat gizi siswa dilakukan dengan metode recall aupan kebiasaan makan. Berdasarkan Tabel 9, siswa SDN Kelapa Dua Wetan 03 Pagi Jakarta Timur rata-rata mengonsumsi energi sehari sebesar 1372.9 kalori dan rata-rata siswa konsumsi protein sebesar 46.5 g. Energi tertinggi yang dikonsumsi siswa pada saat sarapan yaitu 2915,5 kalori dan protein tertinggi dikonsumsi pada saat sarapan yaitu 114,2 g.

Tabel 9 Distribusi frekuensi berdasarkan asupan energi dan protein sehari

\begin{tabular}{lccccc}
\hline Zat gizi & $\mathrm{n}$ & $\overline{\mathrm{x}}$ & Min & Max & SD \\
\hline Energi (Kalori) & 123 & 1372.9 & 558.8 & 2915.5 & 403.5 \\
Protein (g) & 123 & 46.5 & 14.6 & 114.2 & 16.5 \\
\hline
\end{tabular}

\section{Status Gizi}

Penentuan status gizi pada anak menggunakan indeks antropometri IMT/U berdasarkan pengkategorian z-score dibagi menjadi empat kategori yaitu sangat kurus, kurus, normal, gemuk, dan obesitas. Distribusi frekuensi berdasarkan status gizi siswa SDN Kelapa Dua 
Wetan 03 Pagi Jakarta Timur disajikan pada Tabel 9. Berdasarkan Tabel 9. Status gizi siswa di SDN Kelapa Dua Wetan 03 Pagi Jakarta Timur hampir semua dengan status gizi normal $(53.7 \%)$ dan status gizi tertinggi kedua yaitu gemuk/obesitas (17.1\%).

Tabel 10. Distribusi frekuensi berdasarkan status gizi

\begin{tabular}{lcc}
\hline Status gizi & $\mathrm{N}$ & $\%$ \\
\hline Sangat kurus & 4 & 3.3 \\
Kurus & 11 & 8.9 \\
Normal & 66 & 53.7 \\
Gemuk & 21 & 17.1 \\
Obesitas & 21 & 17.1 \\
Jumlah & 123 & 100.0 \\
\hline
\end{tabular}

Dalam penelitian ini status gizi dikelompokkan menjadi dua kategori yaitu normal dan obesitas. Berdasarkan hasil penelitian sebagian besar sampel $(65.9 \%)$ berstatus gizi normal sedangkan sisanya berstatus gizi obesitas dengan persentase $(34.1 \%)$ atau dengan kata lain dapat disimpulkan bahwa prevalensi obesitas pada anak Sekolah Dasar di SDN Kelapa Dua Wetan 03 Pagi Jakarta Timur adalah 34.1\%. Jika dilihat dari kategori sarapan, sebagian besar sampel yang obesitas tidak melakukan sarapan sebelum berangkat ke sekolah yaitu $52.4 \%$.

Berdasarkan hasil uji statistik diperoleh nilai $\mathrm{p}=0.000(\mathrm{p}<0.05)$ sehingga dapat disimpulkan bahwa ada perbedaan yang bermakna antara kebiasaan sarapan dengan status gizi sampel anak SDN Kelapa Dua Wetan 03 Pagi Jakarta Timur. Berdasarkan hasil analisis odds ratio pada Tabel 11, dapat disimpulkan bahwa siswa yang tidak sarapan memiliki 6.2 kali (95\% CI=2.6-14.7) risiko terjadinya obesitas dibanding anak yang sarapan. Hal ini sejalan dengan hasil penelitian yakni anak-anak yang ibu dan ayahnya melewatkan sarapan kemudian lebih banyak untuk mengikuti tidak sarapan dibandingkan dengan mereka yang orang tuanya mencontohkan sarapan kepada anaknya dan anak-anak yang tidak sarapan memiliki 18-116\% peningkatan risiko kelebihan berat badan/obesitas dengan OR $=1.18$ (95\% CI ; 1.05-1.32) dan 2.16 (95\% CI ; 1.55-2.99) ${ }^{20}$.

Penelitian sebelumnya menyatakan bahwa faktor yang mendasari peningkatan jumlah orang obesitas adalah melewatkan sarapan. Hal ini disebabkan anak yang melewatkan sarapan dapat mempengaruhi tingkat nafsu makan anak-anak tetapi bukan meningkatkan asupan energi pada waktu makan berikutnya melainkan mereka secara signifikan kelaparan dan bisa mengonsumsi lebih banyak makanan sebelum makan siang ${ }^{12}$. Dengan demikian maka risiko terjadinya obesitas lebih besar pada anak yang tidak sarapan dibandingkan dengan anak yang sarapan. Hal lain melewatkan sarapan dapat menyebabkan tidak hanya penurunan aktivitas fisik di pagi hari tetapi juga penurunan metabolisme energi. Penurunan konsentrasi gula darah serum akibat melewatkan sarapan mengakibatkan kerusakan jaringan otot melalui jalur glukoneogenik sebagai sarana untuk menyediakan glukosa untuk otak. Ketika lapar mereka dapat menghemat energi dengan membatasi aktivitas fisik yang dapat menghasilkan kondisi dimana tubuh tidak menurunkan berat badan tetapi sebaliknya menambah berat badan dengan mudah ${ }^{8}$.

Anak yang melewatkan sarapan dapat mempengaruhi tingkat nafsu makan anakanak tetapi bukan meningkatkan asupan energi pada waktu makan berikutnya melainkan 
mereka secara signifikan kelaparan dan bisa mengonsumsi lebih banyak makanan sebelum makan siang ${ }^{12}$.

Berdasarkan penelitian terdahulu melewatkan sarapan juga dapat meningkatkan 1.2 kali risiko diabetes tipe 2. Makanan yang dikonsumsi saat sarapan memiliki peranan penting dalam mempengaruhi pelepasan dan aktivitas hormon, sekresi insulin, metabolism lipid dan glukosa. Konsumsi sarapan dapat meningkatkan respon glikemik dan sensitivitas insulin dimana juga dapat mengurangi kadar kolesterol LDL ${ }^{13}$.

Hal serupa sejalan dengan penelitian terdahulu yaitu pria yang melewatkan sarapan memiliki faktor risiko $21 \%$ mengidap diabetes tipe 2 lebih tinggi dibandingkan dengan pria yang mengonsumsi sarapan secara rutin.

Tabel 11. Sebaran status gizi berdasarkan kebiasaan sarapan

\begin{tabular}{llcccccc}
\hline \multirow{2}{*}{$\begin{array}{c}\text { Kebiasaan } \\
\text { Sarapan }\end{array}$} & \multicolumn{4}{c}{ Status gizi } & \multirow{2}{*}{ Total } & OR \\
\cline { 2 - 6 } & \multicolumn{2}{c}{ Obesitas } & \multicolumn{2}{c}{ Normal } & & \\
\cline { 2 - 6 } & $\mathrm{n}$ & $\%$ & $\mathrm{n}$ & $\%$ & $\mathrm{n}$ & $\%$ & \\
\hline Tidak sarapan & 33 & 52.4 & 30 & 47.6 & 63 & 100 & \multirow{2}{*}{6,2} \\
Sarapan & 9 & 15.0 & 51 & 85.0 & 60 & 100 \\
\hline Total & 42 & 34.1 & 81 & 65.9 & 123 & 100
\end{tabular}$\quad(\mathrm{CI}=2,6-14,7)$

\section{Kesimpulan dan Saran}

Siswa SDN Kelapa Dua Wetan 03 Pagi Jakarta Timur mayoritas melewatkan sarapan sebelum berangkat ke sekolah dan hanya sebagian dari siswa yang sarapan secara rutin. Anak yang tidak sarapan mempunyai risiko 6,2 kali untuk obesitas dibandingkan anak yang sarapan.

\section{Referensi}

1. District S, Tenggara N, Province T. Kebiasaan sarapan tidak berhubungan dengan status gizi anak sekolah dasar di Kabupaten Timor Tengah Selatan, Provinsi Nusa Tenggara Timur. 2015;3(2):77-86.

2. Anzarkusuma, I., Mulyani, E., Jus'at, I., \& Angkasa, D. (2014). Status Gizi Berdasarkan Pola Makan Anak Sekolah Dasar Di Kecamatan Rajeg Tangerang (Nutritional Status Based On Primary School Student's Dietary Intake In Rajeg District Tangerang City. Indonesian Journal of Human Nutrition, 1(2), 135-148. Retrieved from https://ijhn.ub.ac.id/index.php/ijhn/article/view/109/115.

3. Sofianita, N., Arini, F., \& Meiyetriani, E. (2015). Peran Pengetahuan Gizi Dalam Menentukan Kebiasaan Sarapan Anak-Anak Sekolah Dasar Negeri Di Pondok Labu, Jakarta Selatan. Jurnal Gizi Dan Pangan, 10(1). doi:http://dx.doi.org/10.25182/jgp.2015.10.1.\%p.

4. Juwita R, Zulhaida, Jumirah. 2015. Pola Konsumsi Sarapan Pagi Murid Sekolah Dasar Di SDN 060921 Kecamatan Medan Sunggal Tahun 2015. (skripsi). Universitas Sumatera Utara, Medan. 
5. Tee, E Siong; Nurliyana, Abdul Razak; Karim, Norimah A; Jan Mohamed, Hamid Jan B; Tan, Sue Yee; Appukutty, Mahenderan; Hopkins, Sinead; Thielecke, Frank; Ong, Moi Kim; Ning, Celia and Mohd Nasir, Mohd Taib. Breakfast consumption among Malaysian Primary and Secondary School Children and Relationship with Body Weight Status - findings from the Mybreakfast Study [online]. Asia Pacific Journal of Clinical Nutrition, Vol. 27, No. 2, 2018: 421-432

6. Yudesti I, Prayitno N. Perbedaan Status Gizi Anak SD Kelas IV Dan V Di SD Unggulan ( 06 Pagi Makasar ) Dan SD Non Unggulan ( 09 Pagi Pinang Ranti ) Kecamatan Makasar Jakarta Timur Tahun 2012. 2013;5(1):2001-5.

7. Niswah, I., Damanik, M., \& Ekawidyani, K. (2014). Kebiasaan Sarapan, Status Gizi, Dan Kualitas Hidup Remaja Smp Bosowa Bina Insani Bogor. Jurnal Gizi Dan Pangan, 9(2). doi:http://dx.doi.org/10.25182/jgp.2014.9.2.\%p

8. Watanabe Y, Saito I, Henmi I, Yoshimura K, Maruyama K, Yamauchi K, et al. Skipping Breakfast is Correlated with Obesity. J Rural Med [Internet]. 2014 [cited 2018 Feb 19];9(2):51-8

9. Nofitasari, A., Anggorodi, R. A., \& Triyanti, T. (2009). Perilaku Sarapan Pagi Dan Kaitannya Dengan Prestasi Belajar Siswi Sekolah Menengah Pertama Di SMPN 2 Depok. Jurnal Kesehatan Masyarakat Andalas, 3(2), 46-52. https://doi.org/10.24893/JKMA.3.2.46-52.2009.

10. Ahmad S, Waluyo, Farissa F. 2012. Hubungan Kebiasaan Sarapan Pagi Dan Jajan Dengan Status Gizi Anak Sekolah Dasar Di SD Negeri Kledokan Depok Sleman Yogyakarta.(Skripsi). Universitas Respati, Yogyakarta.

11. Sopiyandi, S., \& Puspita, W. L. (2016). Analisis jenis, Jumlah dan Mutu Sarapan Pagi siswa sekolah dasar. Jurnal Vokasi Kesehatan, 2(1), 62-68. https://doi.org/10.30602/jvk.v2i1.56

12. Tanja VE Kral, Linda M Whiteford, Moonseong Heo, Myles S Faith; Effects of eating breakfast compared with skipping breakfast on ratings of appetite and intake at subsequent meals in 8- to 10-y-old children, The American Journal of Clinical Nutrition, Volume 93, Issue 2, 1 February 2011, Pages 284-291, https://doi.org/10.3945/ajcn.110.000505

13. Bi, H., Gan, Y., Yang, C., Chen, Y., Tong, X., \& Lu, Z. (2015). Breakfast skipping and the risk of type 2 diabetes: A meta-analysis of observational studies. Public Health Nutrition, 18(16), 3013-3019. doi:10.1017/S1368980015000257.

14. Rania A Mekary, Edward Giovannucci, Walter C Willett, Rob M van Dam, Frank B $\mathrm{Hu}$; Eating patterns and type 2 diabetes risk in men: breakfast omission, eating frequency, and snacking, The American Journal of Clinical Nutrition, Volume 95, Issue 5, 1 May 2012, Pages 1182-1189, https://doi.org/10.3945/ajcn.111.028209.

15. Hardinsyah, H., \& Aries, M. (2016). Jenis Pangan Sarapan Dan Perannya Dalam Asupan Gizi Harian Anak Usia 6-12 Tahun Di Indonesia. Jurnal Gizi Dan Pangan, 7(2), 89-96. doi:http://dx.doi.org/10.25182/jgp.2012.7.2.89-96

16. Brown Larry et al. 2008. Impact Of School Breakfast On Childrens Health And Learning. Harvard School of Public Health. 
17. Sandercock, G. R. H., Voss, C., \& Dye, L. (2010). Associations between habitual schoolday breakfast consumption, body mass index, physical activity and cardiorespiratory fitness in English schoolchildren. European Journal of Clinical Nutrition, 64(10), 10861092. https://doi.org/10.1038/ejen.2010.145

18. Ozdogan Y, Ayse O, Metin S. (2010) The Breakfast Habits Of Female University Students. Pakistan Journal of Nutrition 9 (9): 882-886.

19. Fugas V, Berta E, Walz F, Fortino A, Martinelli MJ. 2013. Breakfast Habit And Quality In Students From Two Public Primary Schools In The City Of Santa Fe. Arch Argent Pediatr ;111(6):502-7.

20. C Okada, Tabutchi T, Iso H. 2017. Association Between Skipping Breakfast In Parents And Children And Childhood Overweight/Obesity Among Children: A Nationwide 10.5-Year Prospective Study In Japan. International Journal of Obesity volume 42, pages 1724-1732. https://doi.org/10.1038/s41366-018-0066-5

21. Meriska, I., Pramudho, K., \& Murwanto, B. (2016). Perilaku Sarapan Pagi Anak Sekolah Dasar. Jurnal Kesehatan, 5(1). doi:http://dx.doi.org/10.26630/jk.v5i1.72 